\title{
The ARF protein in tumor suppression: lessons from mouse models and human tumors
}

\author{
Ignacio Palmero Rodríguez \\ Instituto de Investigaciones Biomédicas CSIC-UAM. Madrid. Spain.
}

\begin{abstract}
The ARF protein is a key mediator of the activation of the p53 tumor suppressor in response to excessive mitogenic signals. ARF is encoded in the INK4a/ARF locus, together with the cell-cycle inhibitor p16INK4a. Mice genetically deficient for ARF show a marked predisposition to tumor formation, supporting an important role for ARF in tumor protection. Alterations of the INK4a/ARF locus are a highly frequent event in human tumors. In some instances, the alterations in the locus result in specific inactivation of ARF. This review will summarise the current knowledge about the biological function and regulation of ARF, and will discuss the evidence from genetically modified murine models, and human tumors which supports a relevant role for ARF in tumor suppression.
\end{abstract}

Key words: ARF, p53, INK4a/ARF locus, tumor suppression, cancer, mouse cancer models.

Palmero Rodriguez I. The ARF protein in tumor suppression: lessons from mouse models and human tumors. Rev Oncol 2004; 6 (2):73-80

\section{La proteína ARF en supresión tumoral: lecciones de modelos animales y tumores humanos}

La proteína ARF es un mediador clave en la activación del supresor tumoral p53, en respuesta a señales mitogénicas inapropiadas. ARF está codificada en el locus INK4a/ARF, junto al regulador de ciclo celular p16INK4a. Ratones genéticamente deficientes para ARF presentan una clara predisposición a la formación de tumores, lo que indica un importante papel de ARF en protección tumoral. Las alteraciones en el locus INK4a/ARF son un fenómeno frecuente en tumores humanos. En algunos casos, estas alteraciones en el locus se traducen en la inactivación específica de ARF. En esta revisión se resume el conocimiento actual sobre la funcion biológica y la regulación de ARF y se comentan las evidencias, procedentes de estudios con animales modificados genéticamente o de tumores humanos, que indican un papel relevante de ARF en supresión tumoral.

Palabras clave: ARF, p53, locus INK4a/ARF, supresión tumoral, cáncer, modelos tumorales en ratones.

\begin{abstract}
The important role of the ARF protein in tumor suppression mechanisms is now well established, thanks to the work of many laboratories over the last eight years, using molecular and cell biology approaches, as well as animal model studies, and genetic analysis of human tumors. This subject has been covered by a number of excellent reviews ${ }^{1-3}$. Here, we will summarise the current knowledge on the role of $\mathrm{ARF}$ in tumor suppression, highlighting the most recent progress in the field.
\end{abstract}

\section{THE BIOLOGY OF ARF}

The locus now known as INK4a/ARF first came to light because of its capacity to encode the cell-cycle

\footnotetext{
Correspondence: Dr. I. Palmero.

Instituto de Investigaciones Biomédicas CSIC-UAM.

Arturo Duperier, 4.

28029 Madrid. Spain.

E-mail: ipalmero@iib.uam.es

Received 20 October 2003; Accepted 20 November 2003
}

inhibitor, and tumor suppressor protein p16INK $4 \mathrm{a}^{4,5}$. The existence of a second "alternative" transcript from the locus, originating from an independent first exon, was described a short time later ${ }^{6-8}$. However, for some time, it was unclear whether this transcript encoded a peptide and if so, which could be its biological relevance. The answer to this uncertainty came a few months later, with the work from the laboratory of Charles Sherr ${ }^{9}$. They first demonstrated the existence of a second protein product from the locus and established the capacity of this novel protein to restrain cell-cycle progression. They also gave ARF its name, after Alternative Reading Frame, based in the fact that the two products of the locus, p16INK4a and ARF, originate from transcripts that share some of their sequences, but are translated using different reading frames (fig. 1). As a consequence, the aminoacid sequences of these two proteins are totally unrelated. The ARF proteins of human and murine origin have been designated p14ARF and p19ARF, respectively, due to their different molecular size ${ }^{9,10}$. From the early reports, it was evident that ARF's action re- 


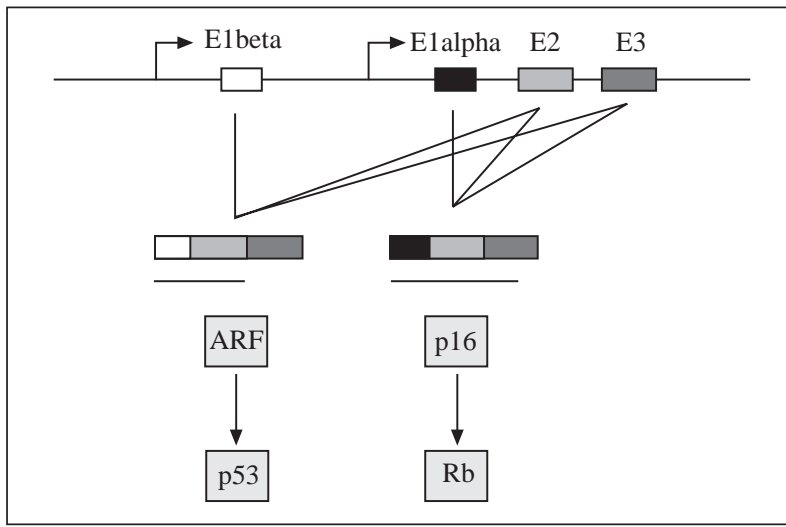

Fig. 1: Structure of the INK4a/ARF locus.

quired the presence of functional $\mathrm{p} 53^{11}$, suggesting that ARF was connected to the tumor suppressor pathway controlled by p53. The molecular nature of this connection was unveiled soon after, when several labs reported the direct interaction of ARF with the oncogene $\mathrm{Mdm} 2$, a transcriptional target of p53 that controls the stability of the p53 protein ${ }^{10,12-14}$. The tumour suppressor p53 plays a central role in a cellular network that responds to a variety of alterations in cell homeostasis which are potentially oncogenic, such as DNA damage, hypoxia, or telomere dysfunction, among many others ${ }^{15}$. Mdm2 is the main responsible for the transient character of p53 activation in response to these stress signals ${ }^{16}$. ARF participates specifically in the activation of p53 in response to a long list of stimuli which have in common the triggering of untimely or excessive mitogenic signals (fig. 2). Thus, the ARF protein is essential for the antiproliferative response of primary cells to the activated Ras oncogene ${ }^{17}$, the proapoptotic responses induced by the viral oncoprotein $\mathrm{E} 1 \mathrm{~A}^{18}$ or the Myc oncogene ${ }^{19}$, or the limited proliferative potential of some primary cells in culture ${ }^{19}$, among others (reviewed in references 1 and 2). The picture that has emerged is that ARF plays a pivotal role in the activation of p53 in response to a variety of inappropriate mitogenic stimuli, such as oncogene activation, or growth under suboptimal conditions, usually designated as "oncogenic stimuli"1. The levels of the ARF protein are extremely low in unstressed normal cells. When cells are exposed to one of the above-described stimuli, the ARF protein accumulates, locating preferentially in the nucleoli. This is generally accompanied by a parallel accumulation of Mdm2 in nucleoli, thereby disrupting the inhibitory interaction between $\operatorname{Mdm} 2$ and p53. The final result of this series of events, and probably others less well known, is the accumulation of transcriptionally active p53 in the nucleus, and the induction of specific responses such as cell-cycle arrest, or apoptosis. This scheme is undoubtedly simplistic and there are accumulating evi-

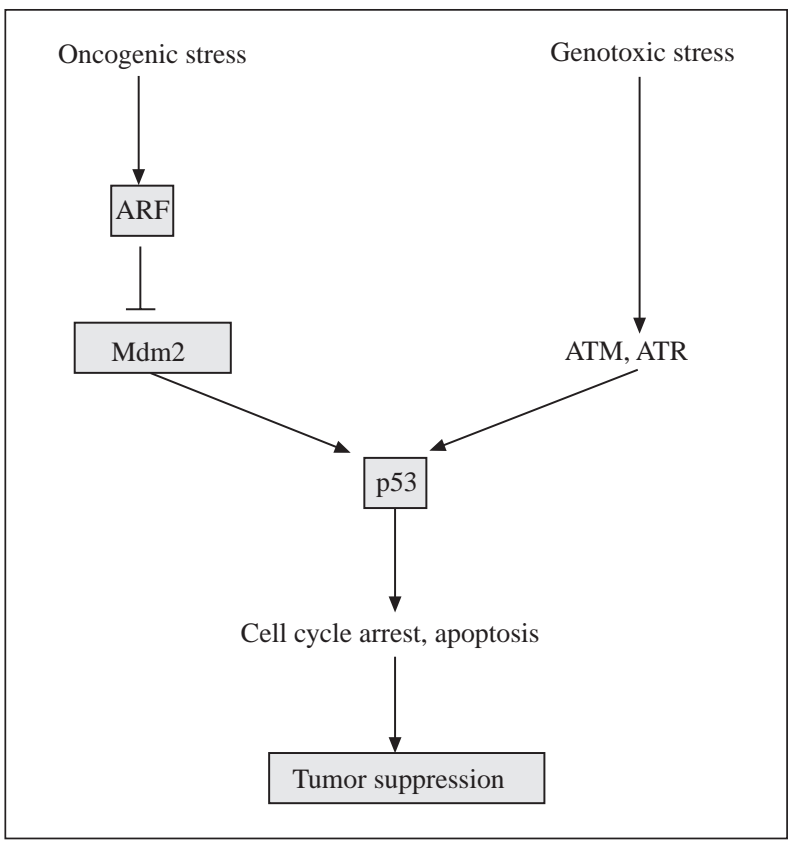

Fig. 2. Schematic representation of the connection between ARF and p53. ARF is the key mediator of a specific signalling pathway that links oncogenic stress signals to p53 via Mdm2. However, ARF can also function independently of Mdm2 and/or p53 (see text). A separate ARF-independent pathway is responsible for p53 activation in response to genotoxic stress, via the kinases ATM and ATR.

dences suggesting alternative and parallel ways of action for ARF.

One of the issues subject to debate about ARF's way of action is the relevance of the nucleolar location of $\mathrm{ARF}$ and the sequestration of Mdm2. It has been shown, using several cell types and under several different experimental stimuli, that ARF can activate p53 without relocating Mdm2 from the nucleoplasm to the nucleoli ${ }^{20-22}$. It has been suggested that a fraction of ARF resides outside the nucleolus and there exerts some ill-defined function to activate p53, possibly through direct inhibition of p53 degradation by $\operatorname{Mdm} 2$, via the ubiquitin proteasome pathway ${ }^{21}$. Nevertheless, an appropriate localisation seems to be important for ARF function. Supporting this view, several tumor-associated mutations in the INK4a/ARF locus result in an abnormal subcellular localisation of ARF, either in nucleoplasm or in cytoplasm ${ }^{23-25}$, and a subset of aggressive B-cell lymphomas has been shown to display a characteristic accumulation of ARF in the nucleoplasm ${ }^{26}$.

Also in contrast with the early linear model connecting ARF to p53 via Mdm2 is the increasing evidence showing that ARF has functions that are independent of p53. Thus, ARF retains its ability to induce cell-cycle arrest in cells lacking $\mathrm{Mdm} 2$ and p53, albeit with reduced efficiency ${ }^{27}$. Also, mice genetically null for p53, Mdm2 and ARF show a spectrum of tumors 
which is clearly different from that of $\mathrm{Mdm} 2 / \mathrm{p} 53$ double knock-out mice ${ }^{27}$, suggesting that they are not fully redundant. Finally, the analysis of p53 and ARF alterations in tumors in mouse models, or in human tumors ${ }^{28,29}$ shows that the inactivation of these genes is not mutually exclusive, suggesting that they are not necessarily in a linear pathway, and are not fully redundant.

Which are these p53-independent functions, and do they involve interaction with novel partners? A large amount of work has been devoted to answering these questions, leading to the identification of novel ARFinteracting proteins, including $\mathrm{MdmX}$, a protein related to $\mathrm{Mdm} 2^{30}$; several members of the E2F family of transcription factors ${ }^{31}$; and the tumor suppressor ING1 (Palmero et al, submitted), among others ${ }^{32-35}$. However, the biological relevance of these interactions, and their importance for ARF function are not clear in many cases. Several examples of p53-independent functions of ARF have recently been described. One of them is the involvement of ARF in transcriptional control, not via p53, but through repression of the NF-kB transcription factor ${ }^{36}$. Also worth mentioning is the observation that ARF can modulate the synthesis of ribosomes, through the inhibition of the processing of ribosomal RNA precursors in the nucleolus, in a p53-independent manner ${ }^{37}$. In this way, ARF would restrain cell proliferation not only by acting upon the cell-cycle machinery, but also by blocking protein synthesis in the cell. It is now clear that $\mathrm{ARF}$ has cellular functions different from the Mdm2mediated stabilisation of $\mathrm{p} 53$, but more work is required to establish the biological relevance of these novel functions of ARF.

\section{UPSTREAM AND DOWNSTREAM OF ARF}

The identification of ARF helped define a novel signalling pathway that connects so-called "oncogenic stimuli" to p53 activation. This pathway acts independently of the ATM/ATR kinase cascade responsible for the activation of $\mathrm{p} 53$ in response to genotoxic stress (fig. 2). Consistent with this, ARF-deficiency has little impact in short term responses to DNA damage $^{11}$. However, some implication of ARF in p53mediated response to genotoxic stress has been suggested, including long-term cell-cycle arrest triggered by genotoxic drugs ${ }^{38}$, or telomere erosion ${ }^{39}$. It has also been suggested that ARF participates in p53 activation and sensitisation to apoptotic stimuli provoked by integrin signalling in some cell types ${ }^{40}$.

The understanding of the signalling pathways that allow ARF to distinguish between the normal mitogenic signals a cell can receive, and inappropriate mitogenic stimuli due to potentially oncogenic stress is of obvious importance. ARF levels are controlled primarily at the transcriptional level and several positive and negative regulators have been identified, including the Bmi polycomb protein ${ }^{41}$, the Myc oncogene ${ }^{19}$, members of the T-box family ${ }^{42}$, Twist ${ }^{43}$, $\mathrm{DMP} 1^{44,45}$, or $\mathrm{E} 2 \mathrm{~F} 1^{46}$. Despite the identification of these regulators, a clear picture of how ARF is activated in response to oncogenic stress is still lacking. ARF transcriptional regulation appears to be rather complex, and probably involves the combined action of some of these transcription factors. This complexity is exemplified by the connections between ARF and the transcription factors of the E2F family. Enforced expression of the E2F1 protein provokes an increase in ARF levels in several cell types in culture ${ }^{21,46}$. However, the biological significance of this observation is unclear. For instance, primary fibroblasts genetically deficient for E2F1, and E2F2 retain normal $A R F$ activation and function in response to a variety of stress signals ${ }^{47}$. Furthermore, in addition to this putative role as upstream regulators, E2F proteins might act downstream of $\mathrm{ARF}$ in its antiproliferative action $^{48}$

Little is known about the downstream mediators responsible for the antiproliferative or proapoptotic effects of ARF. The cell-cycle inhibitor p21CIP1, a direct transcriptional target of $\mathrm{p} 53$, seemed a likely candidate to mediate cell-cycle arrest imposed by ARF. However, the genetic evidence does not support this model, since primary fibroblasts deficient for $\mathrm{p} 21$ remain sensitive to $\mathrm{ARF-mediated} \mathrm{cell-cycle} \mathrm{arrest}{ }^{49}$. As mentioned above, cell-cycle arrest could be partly mediated by ARF-E2F interactions ${ }^{31,48}$. Recent gene expression profiling experiments have led to the identification of several transcriptional regulators, whose expression is increased upon ectopic expression of $\mathrm{ARF}^{50}$. These represent novel candidate downstream effectors, which could mediate some of $A R F^{\prime}$ 's biological functions. It remains to be seen how relevant these gene products are for ARF function in vivo.

\section{ARF IN MOUSE CANCER MODELS}

The most robust evidence linking ARF to tumor suppression has come from the study of genetically engineered mouse models. The availability of genetic tools that allow specific inactivation of the products of one particular locus have shed light on the contribution of each of the products of the INK4a/ARF locus to tumor protection $^{51,52}$. Several mouse models have been generated to inactivate products of the INK4a/ARF locus. Mice in which p19ARF has been genetically inactivated, but retain functional p16, have been obtained by elimination of the ARF-specific exon 1 beta. These animals are highly prone to tumor formation ${ }^{11,53}$. They develop spontaneous tumors of different origins at a relatively early age, being sarcomas, T-cell lymphomas, and squamous cell carcinomas the most pre- 
TABLE 1. Animal models of ARF deficiency

\begin{tabular}{|c|c|c|c|}
\hline Mouse strain & Phenotype & Comments & References \\
\hline ARF - /- & Tumor predisposition & $\begin{array}{l}\text { High incidence of sarcomas (50\%) } \\
\text { and lymphomas (25\%) }\end{array}$ & 11,12 \\
\hline ARF:Mdm2:p53 -/- & Tumor predisposition & $\begin{array}{l}\text { Wider tumor spectrum than ARF-/-, } \\
\text { high incidence of lymphomas (70\%) }\end{array}$ & 27 \\
\hline ARF:ATM -/- & Tumor predisposition & No effect in DNA-damage defects of ATM-/- mice & 12 \\
\hline 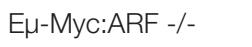 & Lymphoma formation & & $19,57,58,59$ \\
\hline Tyr-Ras:ARF -/- & Melanoma formation & Frequent concomitant inactivation of p16INK4a & $85,86,87$ \\
\hline
\end{tabular}

valent tumors (table 1). They also show an increased sensitivity to several carcinogenic treatments. Mice deficient for p16INK4a, and retaining ARF function $^{54,55}$; or deficient for both products of the locus ${ }^{56}$, have also been generated, allowing to distinguish the contribution of each protein to murine tumorigenesis. Two strains of p16-deficient mice have been generated independently, following different targeting strategies. In both cases, the mice show only a modest general predisposition to tumor formation, but show a significant predisposition to the appearance of melano$\operatorname{mas}^{54,55}$. This is of particular interest, given the evidence linking alterations in the INK4a/ARF locus to melanoma in humans (see below). Finally, INK4a/ARF-deficient mice, deficient for both p16INK4a and p19ARF, show a clear tumor-prone phenotype, with a tumor spectrum similar, but not identical to ARF-null mice ${ }^{56}$.

The availability of several mice strains carrying different genetic alterations in an ARF-null background has allowed investigators to study the functional connections of ARF in vivo (table 1). The use of transgenic mice expressing the Myc oncogene in B-lymphocytes $(E \mu-M y c)$ has been very fruitful to unravel ARF tumor suppressor action, in a series of elegant studies. These mice develop highly aggressive B-cell lymphomas, but only after a long latency with high rates of proliferation and apoptosis in the target cells. A large proportion of the tumors that eventually arise show alterations in ARF, p53, or Mdm2. Consistent with this, $E \mu-M y c$ mice which are genetically deficient for ARF or p53 show an accelerated onset of lymphomas ${ }^{19,57-59}$. These in vivo experiments elegantly recapitulate the observations from cell-culture systems, and clearly indicate that the first response of the cells to the oncogenic stimuli represented by Myc is mounting an apoptotic response mediated by the $\mathrm{ARF} / \mathrm{Mdm} 2 / \mathrm{p} 53$ pathway. The disabling of this pathway is therefore necessary for the appearance of tumors in this experimental setting.

ARF could also influence tumor formation through the control of vascularisation. The phenotypic analy- sis of ARF-deficient mice has revealed a role for ARF in the control of vascular regression during eye development ${ }^{60}$, through the control of proliferation of specialised perivascular tissue. This unexpected function of ARF has fuelled speculations that ARF loss might facilitate tumor growth not only by deregulating proliferation or apoptosis of tumor cells, but also by promoting angiogenesis.

\section{ARF IN HUMAN TUMORS}

In contrast to the compelling evidence obtained from mouse models, the importance of ARF inactivation in human cancer is less clear. The complex structure of the INK4a/ARF locus has hindered the elucidation by classical genetic studies of the specific contribution to human tumorigenesis of each of the products of the locus. Nevertheless, the overall evidence from human tumors supports a more relevant role for p16INK4a in tumor protection in humans (reviewed in reference 61). Most alterations of the INK4a/ARF locus in human tumors are large homozygous deletions, and these usually result in elimination of the entire INK4a/ARF locus, and even other neighbouring loci, with very few exceptions ${ }^{62}$ (see also below). However, when point mutations are considered, the vast majority affect $\mathrm{p} 16 \mathrm{INK} 4 \mathrm{a}^{61}$. No point mutations have yet been reported in the ARF-specific exon 1beta, and those in the common second exon usually have minor effects on ARF function ${ }^{14,63}$. So far, the most prevailing instances of specific inactivation of ARF in human tumors are the reports of silencing of the ARF promoter by cytosine methylation (table 2). Silencing of gene expression by de novo methylation of regulatory regions is a common mechanism for tumor suppressor inactivation in tumors $^{64}$. ARF promoter methylation has been reported in a sizeable fraction (up to $60 \%$ in some tumor types) of human primary tumors, and tumor cell lines, of different origins ${ }^{65-70}$. Methylation of the ARF promoter occurs, in a large proportion of cases, independently of p16INK4a methylation, indicating 
TABLE 2. Alterations of p14ARF in human cancer

\section{Methylation of p14ARF promoter \\ Frequent (40\%-60\%) \\ Moderate (20\%-40\%)}

\section{Mutations in exon 1 beta}

Specific deletion of exon 1 beta

Short deletion in exon 1 beta

Short insertion in exon 1 beta

Mutations in exon 2 affecting ARF $^{a}$

Missense mutations

\author{
Glioblastoma $^{68}$, bladder $^{71}$, oral SCC 94 \\ Colorectal $^{65}$, gastric 6 , breast $^{70}$
}

T-ALL ${ }^{62}$, familial melanoma ${ }^{73}$

Familial melanoma ${ }^{74}$

Familial melanoma ${ }^{25}$

Familial and sporadic melanoma ${ }^{24}$

a: most of these mutations also impair p16INK4a function.

that ARF is specifically targeted in some tumors ${ }^{65}$. Interestingly, the analysis of the methylation status of the ARF promoter using DNA present in plasma ${ }^{71}$, or other fluids ${ }^{72}$ has been used as a prognosis marker for some tumors.

Familial melanoma syndromes are frequently linked to losses in the 9p21 chromosomal region, where the human INK4a/ARF locus is located. Around 50\% of familial melanoma cases show linkage to markers in this region ${ }^{62}$. Of these, a high percentage present mutations in p16INK4a, indicating the importance of p16 alterations in the genesis of melanoma. However, a large number of cases do not show specific alterations in p16, and this has been interpreted as an indication that ARF, or the neighbouring p15INK4b locus, could also be implicated. Interestingly, several instances of specific ARF alterations have been associated to melanoma (table 2). Germline mutations affecting exclusively the p14ARF-specific exon 1 beta have been described in several cases of familial melanoma ${ }^{25,73,74}$. These include the specific deletion of exon 1beta, and short insertions and deletions within exon 1beta. At least in one case, it has been shown that the mutation gives rise to a non-functional p14ARF protein ${ }^{25}$. Also, point mutations linked to melanoma in the common second exon can result in a functionally impaired ARF protein ${ }^{24}$. Taken together, these results suggest that loss of ARF can have a substantial impact in melanoma predisposition in humans.

\section{DIFFERENT ROLE OF ARF IN CELLULAR IMMORTALISATION AND TRANSFORMATION IN HUMAN AND MOUSE}

A possible explanation for the apparently different role of ARF in tumor suppression in human and mice, comes from the studies of the role of ARF in immortalisation, and sensitivity to transformation by oncogenes in primary cells in culture ${ }^{75}$. Normal primary cells show a limited proliferative potential when grown under standard laboratory conditions. After a period of active growth, these cells cease to divide and reach a non-proliferative state, called cellular senescence ${ }^{76}$. In mouse embryonic fibroblasts, the genetic disruption of p19ARF, or p53, is sufficient to allow escape from senescence. These cells are immortal, and can be propagated indefinitely in cultu$\mathrm{re}^{11}$. They have also lost their innate antiproliferative response against oncogenic Ras, and rather become fully transformed ${ }^{11,17}$. In contrast, murine p16INK4adeficient fibroblasts are not immortal per se, nor permissive to transformation by the Ras oncogene $\mathrm{e}^{54,55}$. Human primary cells show a dramatically different behaviour in this respect ${ }^{75,77}$. Immortalisation and transformation of human fibroblasts in culture is under more stringent controls than in mouse cells, and several independent genetic alterations are required including, the activation of telomerase, and the inactivation of the p16 and p53 pathways, besides others less well defined ${ }^{75,77,78}$. However, the relative importance of each of these pathways, and the two products of the INK4a/ARF locus, in human cell immortalisation and transformation is controversial. Recent studies using primary cells from melanoma-prone individuals $^{79-81}$ suggest that loss of p16INK4a, retaining $\mathrm{ARF}$ and $\mathrm{p} 53$ function, facilitates transformation of human fibroblasts. However, independent studies using RNA interference rather suggest a more important role for the p53 pathway, although co-operation between both pathways is required for full transformation $^{82}$. Interestingly, all studies coincide to rule out an important role for p14ARF in this setting, even when p53 is involved. The regulation of ARF is markedly different in human and murine cells. Some of the stimuli known to control ARF expression in mouse cells fail to do so in human cells. This is the case of the Ras oncogene, or the accumulation of divisions in culture $^{79-81,83}$. Therefore, it would appear that, contrary to mouse cells, the protective action of p53 against oncogenic stress in human cells does not involve ARF. How these in vitro observations can be translated to the behaviour of tumors in living organisms is still a challenge, but they should be born in mind for the analysis of genetic alterations of the two products of the locus in human tumors. 


\section{CO-OPERATION BETWEEN ARF AND P16INK4a IN TUMOR SUPPRESSION}

A further level of complexity arises from the growing evidence that there is a significant degree of co-operation between both products of the INK4a/ARF locus. This is best exemplified in the case of melanoma formation, both in mice and humans. As mentioned above, p16INK4a-deficient mice show a modest predisposition to the appearance of melanomas. This phenotype is exacerbated in animals lacking an entire copy of the locus, and carrying a p16 inactivating mutation in the remaining allele ${ }^{54}$. These mice now show a high incidence of melanomas and other tumor types. Therefore loss of p16 can cooperate with ARF heterozygosity, giving rise to a wider spectrum of tumors. Interestingly, this situation in genetically engineered mice closely resembles the situation in many human tumors, where one allele of the locus is deleted and the remaining allele carries inactivating mutations in p16. This is in agreement with the data from human tumors, which indicates that melanoma patients carrying mutations that impair both p16 and p14ARF function show a poor prognosis ${ }^{84}$. Other murine models support important roles both for ARF and p16INK4a in melanoma. Mice genetically engineered to express the oncogenic form of the Ras oncogene in melanocytes (Tyr-Ras) develop melanomas, when crossed onto a genetic background of deficiency of p16INK4a, p19ARF or both products of the INK4a/ARF locus ${ }^{85-87}$ (table 2). Interestingly, animals individually deficient for each one of the products show melanoma predisposition, but frequent somatic inactivation of the remaining product is observed ${ }^{87}$. Therefore loss of either of the products facilitates melanoma formation in this transgenic system, and both products cooperate in melanoma formation. In addition to this effect on the onset of spontaneous melanoma, shared by p16 and p19ARF, the deficiency in ARF specifically results in an increased susceptibility to melanoma induced by UV irradiation. This intriguing observation could be interpreted in different ways: it might reflect a role of $\mathrm{ARF}$ in the repair of DNA damage induced by UV radiation, or alternatively, it might be explained if the main target of UV-induced mutations are in the Rb pathway controlled by $\mathrm{p} 16^{88}$.

Similarly, other complex animal models support the existence of a functional crosstalk between ARF and the Rb pathway. Loss of ARF strongly accelerates the appearance of pituitary tumors in mice heterozygous for the $\mathrm{Rb}$ tumor suppressor ${ }^{89}$. This phenotype is different from that of double Rb/p53-null mice, again supporting the view that ARF has p53-independent functions, important for tumor suppression. Also, primary fibroblasts from animals deficient for the three Rb-related "pocket proteins", Rb, p107 and p130, where the G1-S cell-cycle checkpoint is presumably abolished, are refractile to the antiproliferative action of $\mathrm{ARF}^{90,91}$. Finally, mice doubly deficient for p16INK4a and p53 show an increased predisposition to tumor formation, consistent with a co-operative effect in tumorigenesis of the inactivation of the $\mathrm{p} 16 / \mathrm{Rb}$ and the ARF/p53 pathways ${ }^{92}$.

Recent observations using the above-described $E \mu$ Myc mouse model system have raised the possibility that the two products of the INK4a/ARF locus might play important roles at different stages of tumor formation and remission after chemotherapy ${ }^{93}$. As mentioned, ARF loss favours the onset of lymphomas in this setting, whereas p16 status has little effect at this stage. However, loss of p16 and p53 has a dramatic effect in the regression of these tumors after chemotherapy. These investigators suggest that exposure to chemotherapy drugs triggers both an apoptotic response, mediated by $\mathrm{p} 53$, and an antiproliferative response, similar to senescence, where p16 function is critical. If these observations can be extrapolated to human tumors, the implication would be that the concomitant loss of ARF and p16 can have a dramatic effect in the clinical outcome of tumors, and they suggest that a detailed study of alterations of both products of the INK4a/ARF locus could be important to predict the response of tumors to therapy.

\section{References}

1. Sherr CJ, Weber JD. The ARF/p53 pathway. Curr Opin Genet Dev 2000;10:94-9.

2. Sherr CJ. The ink4a/arf network in tumour suppression. Nat Rev Mol Cell Biol 2001;2:731-7.

3. Lowe SW, Sherr CJ. Tumor suppression by Ink4a-Arf: progress and puzzles. Curr Opin Genet Dev 2003;13:77-83.

4. Serrano M, Hannon GJ, Beach D. A new regulatory motif in cell-cycle control causing specific inhibition of cyclin D/CDK4. Nature 1993;366:704-7.

5. Kamb A, Gruis NA, Weaver-Feldhaus J, et al. A cell cycle regulator potentially involved in genesis of many tumor types. Science 1994;264:436-40.

6. Duro D, Bernard O, Della Valle V, Berger R, Larsen CJ. A new type of p16INK4/MTS1 gene transcript expressed in B-cell malignancies. Oncogene 1995;11:21-9.

7. Mao L, Merlo A, Bedi G, et al. A novel p16INK4A transcript. Cancer Res 1995;55:2995-7.

8. Stone S, Jiang P, Dayananth P, et al. Complex structure and regulation of the P16 (MTS1) locus. Cancer Res 1995;55:2988-94.

9. Quelle DE, Zindy F, Ashmun RA, Sherr CJ. Alternative reading frames of the INK4a tumor suppressor gene encode two unrelated proteins capable of inducing cell cycle arrest. Cell 1995;83:993-1000.

10. Stott FJ, Bates S, James MC, et al. The alternative product from the human CDKN2A locus, p14(ARF), participates in a regulatory feedback loop with p53 and MDM2. Embo J 1998;17:5001-14.

11. Kamijo T, Zindy F, Roussel MF, et al. Tumor suppression at the mouse INK4a locus mediated by the alternative reading frame product p19ARF. Cell 1997;91:649-59.

12. Kamijo T, Weber JD, Zambetti G, Zindy F, Roussel MF, Sherr CJ. Functional and physical interactions of the 
ARF tumor suppressor with p53 and Mdm2. Proc Natl Acad Sci USA 1998;95:8292-7.

13. Pomerantz J, Schreiber-Agus N, Liegeois NJ, et al. The Ink4a tumor suppressor gene product, p19Arf, interacts with MDM2 and neutralizes MDM2's inhibition of p53. Cell 1998;92:713-23.

14. Zhang Y, Xiong Y, Yarbrough WG. ARF promotes MDM2 degradation and stabilizes p53: ARF-INK4a locus deletion impairs both the $\mathrm{Rb}$ and $\mathrm{p} 53$ tumor suppression pathways. Cell 1998;92:725-34.

15. Vogelstein B, Lane D, Levine AJ. Surfing the p53 network. Nature 2000;408:307-10.

16. Michael D, Oren M. The p53-Mdm2 module and the ubiquitin system. Semin Cancer Biol 2003;13:49-58.

17. Palmero I, Pantoja C, Serrano M. p19ARF links the tumour suppressor p53 to Ras. Nature 1998;395:125-6.

18. De Stanchina E, McCurrach ME, Zindy F, et al. E1A signaling to p53 involves the p19(ARF) tumor suppressor. Genes Dev 1998;12:2434-42.

19. Zindy F, Eischen CM, Randle DH, et al. Myc signaling via the ARF tumor suppressor regulates p53-dependent apoptosis and immortalization. Genes Dev 1998;12:2424-33.

20. Lin AW, Lowe SW. Oncogenic ras activates the ARF-p53 pathway to suppress epithelial cell transformation. Proc Natl Acad Sci USA 2001;98:5025-30.

21. Llanos S, Clark PA, Rowe J, Peters G. Stabilization of p53 by p14ARF without relocation of MDM2 to the nucleolus. Nat Cell Biol 2001;3:445-52.

22. Korgaonkar C, Zhao L, Modestou M, Quelle DE. ARF function does not require p53 stabilization or Mdm2 relocalization. Mol Cell Biol 2002;22:196-206.

23. Zhang Y, Xiong Y. Mutations in human ARF exon 2 disrupt its nucleolar localization and impair its ability to block nuclear export of MDM2 and p53. Mol Cell 1999;3:579-91.

24. Rizos H, Darmanian AP, Holland EA, Mann GJ, Kefford RF. Mutations in the INK4a/ARF melanoma susceptibility locus functionally impair p14ARF. J Biol Chem 2001;276:41424-34.

25. Rizos H, Puig S, Badenas C, et al. A melanoma-associated germline mutation in exon 1beta inactivates p14ARF. Oncogene 2001;20:5543-7.

26. Sánchez-Aguilera A, Sánchez-Beato M, García JF, Prieto I, Pollan M, Piris MA. p14(ARF) nuclear overexpression in aggressive B-cell lymphomas is a sensor of malfunction of the common tumor suppressor pathways. Blood 2002;99:1411-8.

27. Weber JD, Jeffers JR, Rehg JE, et al. p53-independent functions of the p19(ARF) tumor suppressor. Genes Dev 2000;14:2358-65.

28. Sánchez-Cespedes M, Reed AL, Buta M, et al. Inactivation of the INK4A/ARF locus frequently coexists with TP53 mutations in non-small cell lung cancer. Oncogene 1999;18:5843-9.

29. Bradley G, Irish J, MacMillan C, et al. Abnormalities of the ARF-p53 pathway in oral squamous cell carcinoma. Oncogene 2001;20:654-8.

30. Jackson MW, Lindstrom MS, Berberich SJ. MdmX binding to ARF affects Mdm2 protein stability and p53 transactivation. J Biol Chem 2001;276:25336-41.

31. Eymin B, Karayan L, Seite P, et al. Human ARF binds E2F1 and inhibits its transcriptional activity. Oncogene 2001;20:1033-41.

32. Vivo M, Calogero RA, Sansone F, et al. The human tumor suppressor arf interacts with spinophilin/neurabin II, a type 1 protein-phosphatase-binding protein. J Biol Chem 2001;276:14161-9.

33. Fatyol K, Szalay AA. The p14ARF tumor suppressor protein facilitates nucleolar sequestration of hypoxia-indu- cible factor-1alpha (HIF-1alpha) and inhibits HIF-1mediated transcription. J Biol Chem 2001;276:28421-9.

34. Sugihara T, Kaul SC, Kato J, Reddel RR, Nomura H, Wadhwa R. Pex19p dampens the p19ARF-p53-p21WAF1 tumor suppressor pathway. J Biol Chem 2001;276:18649-52.

35. Hasan MK, Yaguchi T, Sugihara T, et al. CARF is a novel protein that cooperates with mouse p19ARF (human p14ARF) in activating p53. J Biol Chem 2002;277:37765-70.

36. Rocha S, Campbell KJ, Perkins ND. p53- and Mdm2-Independent Repression of NF-kappaB Transactivation by the ARF Tumor Suppressor. Mol Cell 2003;12:15-25.

37. Sugimoto M, Kuo ML, Roussel MF, Sherr CJ. Nucleolar Arf tumor suppressor inhibits ribosomal RNA processing. Mol Cell 2003;11:415-24.

38. Khan SH, Moritsugu J, Wahl GM. Differential requirement for p19ARF in the p53-dependent arrest induced by DNA damage, microtubule disruption, and ribonucleotide depletion. Proc Natl Acad Sci USA 2000;97:3266-71.

39. Smogorzewska A, de Lange T. Different telomere damage signaling pathways in human and mouse cells. Embo J 2002;21:4338-48.

40. Lewis JM, Truong TN, Schwartz MA. Integrins regulate the apoptotic response to DNA damage through modulation of p53. Proc Natl Acad Sci USA 2002;99:3627-32.

41. Jacobs JJ, Kieboom K, Marino S, DePinho RA, van Lohuizen M. The oncogene and Polycomb-group gene bmi-1 regulates cell proliferation and senescence through the ink4a locus. Nature 1999;397:164-8.

42. Jacobs JJ, Keblusek P, Robanus-Maandag E, et al. Senescence bypass screen identifies TBX2, which represses cdkn2a (p19ARF) and is amplified in a subset of human breast cancers. Nat Genet 2000;26:291-9.

43. Maestro R, Dei Tos AP, Hamamori Y, et al. Twist is a potential oncogene that inhibits apoptosis. Genes Dev 1999;13:2207-17.

44. Inoue K, Roussel MF, Sherr CJ. Induction of ARF tumor suppressor gene expression and cell cycle arrest by transcription factor DMP1. Proc Natl Acad Sci USA 1999;96:3993-8

45. Inoue K, Wen R, Rehg JE, et al. Disruption of the ARF transcriptional activator DMP1 facilitates cell immortalization, Ras transformation, and tumorigenesis. Genes Dev 2000;14:1797-809.

46. Bates S, Phillips AC, Clark PA, et al. p14ARF links the tumour suppressors RB and p53. Nature 1998;395:124-5.

47. Palmero I, Murga M, Zubiaga A, Serrano M. Activation of ARF by oncogenic stress in mouse fibroblasts is independent of E2F1 and E2F2. Oncogene 2002;21:2939-47.

48. Rowland BD, Denissov SG, Douma S, Stunnenberg HG, Bernards R, Peeper DS. E2F transcriptional repressor complexes are critical downstream targets of p19(ARF)/p53-induced proliferative arrest. Cancer Cell 2002;2:55-65.

49. Pantoja C, Serrano M. Murine fibroblasts lakring p21 undergo senescence and are resistant to transformation by oncogenic Ras. Oncogene 1999;18:4974-82.

50. Kuo ML, Duncavage EJ, Mathew R, et al. Arf induces p53-dependent and -independent antiproliferative genes. Cancer Res 2003;63:1046-53.

51. Serrano M. The INK4a/ARF locus in murine tumorigenesis. Carcinogenesis 2000;21:865-9.

52. Sherr CJ. Parsing Ink4a/Arf. "Pure" p16-Null Mice. Cell 2001;106:531-4

53. Kamijo T, Bodner S, van de Kamp E, Randle DH, Sherr CJ. Tumor spectrum in ARF-deficient mice. Cancer Res 1999;59:2217-22.

54. Krimpenfort P, Quon KC, Mooi WJ, Loonstra A, Berns A. Loss of p16Ink4a confers susceptibility to metastatic melanoma in mice. Nature 2001;413:83-6. 
55. Sharpless NE, Bardeesy N, Lee KH, et al. Loss of p16Ink4a with retention of p19Arf predisposes mice to tumorigenesis. Nature 2001;413:86-91.

56. Serrano M, Lee H, Chin L, Cordon-Cardo C, Beach D, DePinho RA. Role of the INK4a locus in tumor suppression and cell mortality. Cell 1996;85:27-37.

57. Jacobs JJ, Scheijen B, Voncken JW, Kieboom K, Berns A, van Lohuizen M. Bmi-1 collaborates with c-Myc in tumorigenesis by inhibiting c-Myc- induced apoptosis via INK4a/ARF. Genes Dev 1999;13:2678-90.

58. Eischen CM, Weber JD, Roussel MF, Sherr CJ, Cleveland JL. Disruption of the ARF-Mdm2-p53 tumor suppressor pathway in Myc-induced lymphomagenesis. Genes Dev 1999;13:2658-69.

59. Schmitt CA, McCurrach ME, de Stanchina E, WallaceBrodeur RR, Lowe SW. INK4a/ARF mutations accelerate lymphomagenesis and promote chemoresistance by disabling p53. Genes Dev 1999;13:2670-7.

60. McKeller RN, Fowler JL, Cunningham JJ, et al. The Arf tumor suppressor gene promotes hyaloid vascular regression during mouse eye development. Proc Natl Acad Sci USA 2002;99:3848-53.

61. Ruas M, Peters G. The p16INK4a/CDKN2A tumor suppressor and its relatives. Biochim Biophys Acta 1998; 1378:F115-77.

62. Gardie B, Cayuela JM, Martini S, Sigaux F. Genomic alterations of the p19ARF encoding exons in T-cell acute lymphoblastic leukemia. Blood 1998;91:1016-20.

63. Quelle DE, Cheng M, Ashmun RA, Sherr CJ. Cancer-associated mutations at the INK4a locus cancel cell cycle arrest by p16INK4a but not by the alternative reading frame protein p19ARF. Proc Natl Acad Sci USA 1997;94:669-73.

64. Esteller M. Cancer epigenetics: DNA methylation and chromatin alterations in human cancer. Adv Exp Med Biol 2003;532:39-49.

65. Esteller M, Tortola S, Toyota M, et al. Hypermethylationassociated inactivation of $\mathrm{p} 14(\mathrm{ARF})$ is independent of p16(INK4a) methylation and p53 mutational status. Cancer Res 2000;60:129-33.

66. Iida S, Akiyama Y, Nakajima T, et al. Alterations and hypermethylation of the p14(ARF) gene in gastric cancer Int J Cancer 2000;87:654-8.

67. Esteller M, Cordon-Cardo C, Corn PG, et al. p14ARF silencing by promoter hypermethylation mediates abnormal intracellular localization of MDM2. Cancer Res 2001;61:2816-21.

68. Nakamura M, Watanabe T, Klangby U, et al. p14ARF deletion and methylation in genetic pathways to glioblas tomas. Brain Pathol 2001;11:159-68.

69. Watanabe T, Nakamura M, Yonekawa Y, Kleihues P, Ohgaki H. Promoter hypermethylation and homozygous deletion of the p14ARF and p16INK4a genes in oligodendrogliomas. Acta Neuropathol 2001;101:185-9.

70. Silva J, Silva JM, Domínguez G, et al. Concomitant expression of p16INK4a and p14ARF in primary breast cancer and analysis of inactivation mechanisms. J Pathol 2003;199:289-97.

71. Domínguez G, Carballido J, Silva J, et al. p14ARF promoter hypermethylation in plasma DNA as an indicator of disease recurrence in bladder cancer patients. Clin Cancer Res 2002;8:980-5.

72. Klump B, Hsieh CJ, Dette S, et al. Promoter Methylation of INK4a/ARF As Detected in Bile-Significance for the Differential Diagnosis in Biliary Disease. Clin Cancer Res 2003;9:1773-8.

73. Randerson-Moor JA, Harland M, Williams S, et al. A germline deletion of p14(ARF) but not CDKN2A in a melanoma-neural system tumour syndrome family. Hum Mol Genet 2001;10:55-62.
74. Hewitt C, Lee Wu C, Evans G, et al. Germline mutation of ARF in a melanoma kindred. Hum Mol Genet 2002;11:1273-9.

75. Drayton S, Peters G. Immortalisation and transformation revisited. Curr Opin Genet Dev 2002;12:98-104.

76. Serrano M, Blasco MA. Putting the stress on senescence. Curr Opin Cell Biol 2001;13:748-53.

77. Hahn WC, Weinberg RA. Modelling the molecular circuitry of cancer. Nat Rev Cancer 2002;2:331-41.

78. Hahn WC, Counter CM, Lundberg AS, Beijersbergen RL, Brooks MW, Weinberg RA. Creation of human tumour cells with defined genetic elements. Nature 1999;400:464-8.

79. Brookes S, Rowe J, Ruas M, et al. INK4a-deficient human diploid fibroblasts are resistant to RAS-induced senescence. Embo J 2002;21:2936-45.

80. Huot TJ, Rowe J, Harland M, et al. Biallelic Mutations in p16(INK4a) Confer Resistance to Ras- and Ets- Induced Senescence in Human Diploid Fibroblasts. Mol Cell Biol 2002;22:8135-8143

81. Drayton S, Rowe J, Jones R, et al. Tumor suppressor p16(INK4a) determines sensitivity of human cells to transformation by cooperating cellular oncogenes. Cancer Cell 2003;4:301-10.

82. Voorhoeve PM, Agami R. The tumor-suppressive functions of the human INK4A locus. Cancer Cell 2003;4: 311-9.

83. Wei W, Hemmer RM, Sedivy JM. Role of p14(ARF) in replicative and induced senescence of human fibroblasts. Mol Cell Biol 2001;21:6748-57.

84. Holland EA, Schmid H, Kefford RF, Mann GJ. CDKN2A (P16(INK4a)) and CDK4 mutation analysis in 131 Australian melanoma probands: effect of family history and multiple primary melanomas. Genes Chromosomes Cancer 1999;25:339-48.

85. Chin L, Pomerantz J, Polsky D, et al. Cooperative effects of INK4a and ras in melanoma susceptibility in vivo. Genes Dev 1997;11:2822-34.

86. Sharpless E, Chin L. The INK4a/ARF locus and melanoma. Oncogene 2003;22:3092-8.

87. Sharpless NE, Kannan K, Xu J, Bosenberg MW, Chin L. Both products of the mouse Ink4a/Arf locus suppress melanoma formation in vivo. Oncogene 2003;22:5055-9.

88. Kannan K, Sharpless NE, Xu J, O'Hagan RC, Bosenberg M, Chin L. Components of the Rb pathway are critical targets of UV mutagenesis in a murine melanoma model. Proc Natl Acad Sci USA 2003;100:1221-5.

89. Tsai KY, MacPherson D, Rubinson DA, et al. ARF mutation accelerates pituitary tumor development in $\mathrm{Rb}+/-$ mice. Proc Natl Acad Sci USA 2002;99:16865-70.

90. Dannenberg JH, van Rossum A, Schuijff L, te Riele H. Ablation of the retinoblastoma gene family deregulates G(1) control causing immortalization and increased cell turnover under growth- restricting conditions. Genes Dev 2000;14:3051-64.

91. Sage J, Mulligan GJ, Attardi LD, et al. Targeted disruption of the three Rb-related genes leads to loss of G(1) control and immortalization. Genes Dev 2000;14: 3037-50.

92. Sharpless NE, Alson S, Chan S, Silver DP, Castrillon DH, DePinho RA. p16(INK4a) and p53 deficiency cooperate in tumorigenesis. Cancer Res 2002;62:2761-5.

93. Schmitt CA, Fridman JS, Yang M, et al. A senescence program controlled by $\mathrm{p} 53$ and p16INK4a contributes to the outcome of cancer therapy. Cell 2002;109:335-46.

94. Shintani S, Nakahara Y, Mihara M, Ueyama Y, Matsumura T. Inactivation of the p14(ARF), p15(INK4B) and $\mathrm{p} 16$ (INK4A) genes is a frequent event in human oral squamous cell carcinomas. Oral Oncol 2001;37:498-504. 